\title{
Wiesława Sajdek
}

Akademia im. Jana Długosza w Częstochowie

\section{PO WOJNIE. PEDAGOGICZNE IDEAŁY W WYBRANYCH ARTYKUŁACH Z LAT 1945-1949}

\section{After the War. The Ideals of Pedagogy in Selected Articles Published in the Period 1945-1949}

Summary: The article offers an analysis of selected passages taken from the Polish press, which were published after the end of World War II, in extremely difficult conditions. The analysis is based on excerpts from "Praca Szkolna" ("School Work") and "Życie Szkoły" ("School Life") as well as other periodicals issued at that time. The articles in question, which dissused the issue of educational ideals, referred to prewar projects. They were grounded in clear axiology and the philosophy of man, and they found reflection in specific programme proposals. Education was to address chiefly "the repair of war damage". Under the influence of the political tendencies which contributed to "the new Polish reality", the wording of the articles was changing. Socialist ideology with its newspeak gradually supplanted all traces of the debate on values in pedagogy.

Keywords: historical watershed, war as watershed, unchangeable ideal, new agressive ideology

1 Dr hab. Wiesława Sajdek, prof. AJD w Częstochowie - kierownik Zakładu Historii Filozofii w Instytucie Filozofii Wydziału Filologiczno-Historycznego Akademii im. Jana Długosza w Częstochowie. Adres: Zakład Historii Filozofii AJD, ul. Waszyngtona 4/8, 42-200 Częstochowa; e-mail: wsajdek@gmail.com. 


\section{Wstęp}

„Musimy zwolna, stopniowo przyzwyczajać się do lepszych form bytowania, budzić się niejako z letargu straszliwego, bo jeszcze jesteśmy ogluszeni warkotem maszyn i pocisków burzących wszystko, co było kwitnące i piękne”2.

Czy współczesna pedagogika zawiera treści, które pogłębiają sens istnienia człowieka, a także wartość tego istnienia oraz jego piękno? Czy nastawiona jest przede wszystkim na wartości duchowe? ${ }^{3}$ Obejmują one swoim zakresem, oprócz religii, także filozofię, a wypełniając życie wewnętrzne człowieka, tworzą jego kulturę ${ }^{4}$ Tuż po wojnie polscy pedagodzy byli świadomi zarówno rangi i roli wartości duchowych w wychowaniu, jak i ich zakorzenienia w kulturze starożytnej.

W starożytnej Grecji funkcjonowało pojęcie $\pi \alpha \iota \delta \varepsilon i a^{5}$, oznaczające wychowywanie dzieci, a zarazem cel tego wychowywania. Paideia jako ćwiczenie i uczenie stanowiła oppositum do pojęcia $\tau \rho \circ \varphi \eta^{6}$, oznaczającego żywność, pokarm, ale także opiekę nad dzieckiem. Krótko mówiąc - wychowanie, lecz tylko w aspekcie biologicznym. Do istotnych wartości starogreckiej paidei należała wrażliwość

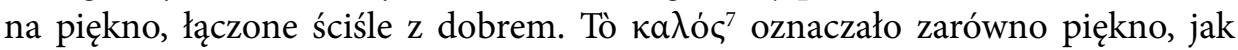
i szlachetność oraz zacność ${ }^{8}$. Te wartości decydowały o jakości ludzkiego życia. Kształcenie umysłu i wychowanie obywatela, dwa istotne cele pedagogiki, z pewnością mają swoje starożytne źródła. Do tego dochodzi trzeci cel: „Wychować człowieka kulturalnego i duchowo pogłębionego"9. Tuż po wojnie podkreślano ten trzeci wymiar pedagogiki. Wydawać by się mogło, że powojenne braki dotyczyły głównie niedostatków wykształcenia, a także zubożenia, lub wręcz zaniku właściwych relacji międzyludzkich. Pisano więc o „walce ze zdziczeniem”. Hele-

2 Michał Dadlez, „Utwór literacki jako czynnik wychowania estetycznego”. Praca Szkolna 8 (1948): 18.

3 Koncepcja wychowania personalistycznego, opracowana przez Karola Górskiego (19031988), zawiera filozoficzne uzasadnienie właściwego usytuowania świata duchowego w perspektywie pedagogicznej: „K. Górski wyróżnia świat dostępny zmysłom i świat duchowy. [...] w «obrębie świata duchowego znajduje się świat wolności»”. Janina Kostkiewicz, Kierunki i koncepcje pedagogiki katolickiej w Polsce 1918-1939 (Kraków: Oficyna Wydawnicza „Impuls” 2013), 373.

4 „Rozróżnienie «cywilizacji» $\mathrm{i}$ «kultury» jako dwóch różnych pojęć było od dawna uwzględniane, ale dopiero ostatnia wojna stała się okrutną, poglądową lekcją, która nauczyła nas w sposób wyraźny odróżniać te pojęcia”. Władysława Hoszowska, „Szkoła polska a ruch spółdzielczy”. Praca Szkolna 1-2 (1946): 9.

5 Słownik grecko-polski, red. Zofia Abramowiczówna (Warszawa: Państwowe Wydawnictwo Naukowe 1962), 362.

6 Tamże, 1965, 366.

7 Tamże, 1960, 552.

8 Władysław Tatarkiewicz, Historia estetyki, t. I (Wrocław - Warszawa - Kraków: Zakład Narodowy im. Ossolińskich - Wydawnictwo 1962), 45.

9 Stefan Szuman, „Myśli o kształtowaniu kultury estetycznej - wychowawców i wychowanków nowej szkoły polskiej”. Praca Szkolna 1-2 (1945): 4. 
na Radlińska jako jego przejawy wymieniała brutalność w stosunku do obcych i poniewieranie słabszymi, a przyczyną takich zachowań był bardzo często alkoholizm: „Wielką rolę może odegrać Kościół, który w dawniejszych epokach nasilenia pijaństwa prowadził skuteczną propagandę wstrzemięźliwości”10. Radlińska pisała: „We wszystkich pracach liczyć się trzeba z koniecznością jak najrealniejszego ujmowania zagadnień i równocześnie - ukazywanie ideału, ku któremu mamy pójść i prowadzić" ${ }^{11}$.

Skupianie uwagi na zdobywaniu podstawowych środków do życia oraz zagrożenia życia ze strony niemieckich okupantów nie sprzyjały rozwojowi kultury. Bardzo trudne okoliczności sprawiały jednak, że ważne działania kulturalne i naukowe, które wtedy miały miejsce, angażowały wyjątkowo wiele ludzkich wysiłków, poświęcenia i czasu. Chodziło o ratowanie człowieczeństwa. Z okupacją łączyła się bowiem: „Całkowita likwidacja szkoły lub pozostawienie jej w postaci programowo skarłowaciałej, będącej przykrą, wręcz niestrawną namiastką instytucji przedwojennej"12. Pisał Ludwik Bandura:

Wiemy, że uczeni nasi jak i pedagogowie praktycy w czasie wojny nie próżnowali. Z londyńskich „Wiadomości Nauczycielskich”, które zaczynają dochodzić do kraju, dowiadujemy się, że i nasi koledzy za granicą wiele ciekawych prac do druku przygotowali. Plany wydawnicze naszej organizacji i księgarń nakładowych na najbliższą przyszłość powinny wziąć pod uwagę potrzebę udostępnienia tych prac szerokiemu ogółowi nauczycieli i społeczeństwa ${ }^{13}$.

Zarówno podczas wojny, jak i tuż po niej istniała świadomość wagi i znaczenia kultury duchowej dla poszczególnego człowieka oraz „odradzającego się narodu polskiego", jak wówczas pisano. Wychowanie estetyczne w szkole było jednym z celów ówczesnego Ministerstwa Oświaty ${ }^{14}$. Ważną rolę w wychowaniu estetycznym spełnił miesięcznik „Nauka i Sztuka”, którego pierwszy numer ukazał się w 1945 roku. Publikowali tam m.in. Hanna Malewska, Czesław Miłosz, Wacław Borowy, Adam Krzyżanowski, Mieczysław Jastrun, Julian Przyboś i Leopold Staff.

Świadomość łączności estetyki z filozofią nie była w Polsce niczym nowym. A oto wypowiedź Maurycego Mochnackiego, z artykułu pt. Myśli o literaturze

10 Helena Radlińska, „Szkoła w walce z ujemnymi skutkami wojny w dziedzinie moralności”. Praca Szkolna 9-10 (1947): 370-371.

11 Tamże, 373.

12 Wacław Wojtyński, „Ćwiczenia słownikowe w nowym programie szkoły powszechnej”. Praca Szkolna 1-2 (1945): 31.

13 Ludwik Bandura, „O wznowienie wydawnictw pedagogicznych”. Praca Szkolna 4 (1946): 131. „W dziedzinie wydawnictw książek pedagogicznych do tej pory obserwujemy zastój. Tych kilka pozycji, które wydały do tej pory Nasza Ksiegarnia i Księgarnia św. Wojciecha, są kroplą w morzu wobec olbrzymich potrzeb w tej dziedzinie". Tamże.

14 „Ministerstwo Oświaty w nowo powstających programach nauczania i wychowania kładzie duży nacisk na wychowanie estetyczne w szkole”. Kazimierz Czarnowski, „Głos w dyskusji”. Praca Szkolna 4 (1946): 126. 
polskiej (po raz pierwszy ten tekst ukazał się w „Gazecie Polskiej”, nr 89-94, z 29 III-3 IV 1828 roku):

Kiedy filozofia zastosowana do ogółu poznawań, a zatem wszechstronna w założeniach i rezultatach swoich, zgodna z prawdami religijnymi i od nich wspierana [...], sterem publicznego oświecenia kieruje, naówczas ukształcenie młodzieży pod względem naukowym, moralnym i estetycznym mniej zależy na przypadkowych okolicznościach, ale jest sprawą rozumu, sprawą wewnętrznej wolności jestestw nim obdarzonych ${ }^{15}$.

Pedagodzy powojenni zdawali sobie sprawę z wagi i znaczenia kulturowej tradycji: „[...] odrzucenie spadku przeszłości w dziedzinie tak zwanej «duchowej» czy humanistycznej [...], chwilowo nawet niedostrzegalne, powoduje ogromne spustoszenia” ${ }^{16}$. Współcześnie są już one wyraźnie widocznie.

W dalszej części artykułu przedstawione zostaną opinie oraz postulaty, a także konkretne plany zawarte $\mathrm{w}$ artykułach znajdujących się przede wszystkim w dwóch wybranych powojennych periodykach pedagogicznych: „Pracy Szkolnej” i „Życiu Szkoły”. Oba dotyczą szkolnej praktyki. Wydało się czymś wyjątkowo interesującym, jak i dlaczego tak wiele uwagi i troski ówcześni pedagodzy poświęcali sprawie wychowania estetycznego. Za tą postawą możemy bowiem odnaleźć określoną filozofię człowieka, w której piękno ludzkiego życia, zarówno w aspekcie etycznym, jak i estetycznym, pozostaje w najściślejszej łączności z jego sensem.

\section{Rola i ranga wychowania estetycznego w likwidacji skutków wojny}

Przy końcu 1945 roku ukazały się pierwsze numery miesięcznika „Praca Szkolna”. Był to „organ Wydziału Pedagogicznego Związku Nauczycielstwa Polskiego poświęcony praktyce wychowania i nauczania”. A oto początek redakcyjnego „wstępniaka”:

Minęło 6 lat od czasu ukazania się ostatniego numeru „Pracy Szkolnej”. W okresie pożogi wojennej, która ogarnęła cały kraj podczas tej najstraszliwszej z wojen,

15 Maurycy Mochnacki, Rozprawy literackie (Wrocław: Zakład Narodowy im.Ossolińskich Wydawnictwo 2004), 104-105.

16 Kazimierz Miężyński, „Rola pomocy naukowych na lekcjach jezyka polskiego w Polsce dzisiejszej”. Praca Szkolna 5-6 (1947): 222. „Na Polsce dokonano bodaj najstraszliwszego w dziejach bo popełnionego z całą świadomością, premedytacją, eksperymentu - przerwano ciąg naszej kultury humanistycznej w sposób «naukowy»". Tamże. 
jaką ludzkość przeżyła - zniknąć musiało z widowni życia - lub zejść w podziemia wszystko to, co syciło życie człowieka treścią, pogłębiającą sens, wartość, piękno jego istnienia ${ }^{17}$.

I uzupełnienie: „Do tych trudności, jakie nauczycielowi przyniosła wojna, dołączyła się zmiana w strukturze naszego bytu politycznego, społecznego i kulturalnego, objęta ogólnym mianem «nowej, polskiej rzeczywistości»"18. Zamieszczone teksty wydają się wolne od bezpośrednich uwikłań politycznych. Zarówno pierwszy artykuł, autorstwa Stefana Szumana, który odwoływał się do obrad Ogólnopolskiego Zjazdu Oświaty w Łodzi (18-22 VI 1945 roku; projektowana wtedy reforma oświaty dążyła do upowszechnienia kultury estetycznej) ${ }^{19}$, jak i wcześniejsze uwagi „Od Redakcji” zawierają przekonujące wyjaśnienie, dlaczego estetyka jest aż tak ważna. Dotyczy ona bowiem „kształtowania najgłębszych warstw istoty człowieka" ${ }^{20}$.

Najważniejsze zagadnienia programowe powojennej polskiej szkoły dotyczyły nauczania języka polskiego. Podkreślano, że „zadania wychowawcze i poznawcze języka polskiego wiążą się najściślej z wychowaniem estetycznym”21. Było ono związane z podstawową dyrektywą ówczesnej praktyki pedagogicznej, określaną jako „likwidacja skutków wojny”. S. Szuman wymieniał dziedziny, które powinny zostać objęte kształceniem estetycznym: muzyka, plastyka, utwory literatury pięknej, taniec, teatr i kino - „w tej mierze, w jakiej produkcje kinowe nie tylko bawią, uczą, społecznie wychowują, lecz są utworami smaku artystycznego i dziełami sztuki odrębnego rodzaju"22. O filmie pisano entuzjastycznie, acz nie bez zastrzeżeń: „[...] film [...] jeżeli będzie służył prawdzie, stanie się istotnie czynnikiem najwyższego dobra. W tej właśnie postaci film, stając do wyścigu z książką, wkracza do współczesnej szkoły jako najdoskonalsze narzędzie pracy pedagoga”23. Jeśli chodzi o muzykę, pisał już wówczas: „Niestety, dzieci nasze słyszą wokoło siebie tyle muzyki tandentnej i wulgarnej, że ich naturalny dobry smak muzyczny rychło się wypacza"24. Szuman podkreślał ważność pedagogicznych wysiłków, skupionych na staraniach wokół wychowania człowieka w jego „człowieczej istocie”, mając na myśli przede wszystkim „dobrze przygotowanych odbiorców sztuki”. Wychowanie artystyczne, dotyczące wykonawców oraz samych twórców, jest tylko wierzchołkiem piramidy, ktrórej szeroką podstawę stanowi wychowanie odbiorców wartości estetycznych, pośród których najważniejsze jest piękno. Nie każdy może zostać artystą, ale zdecydowana większość

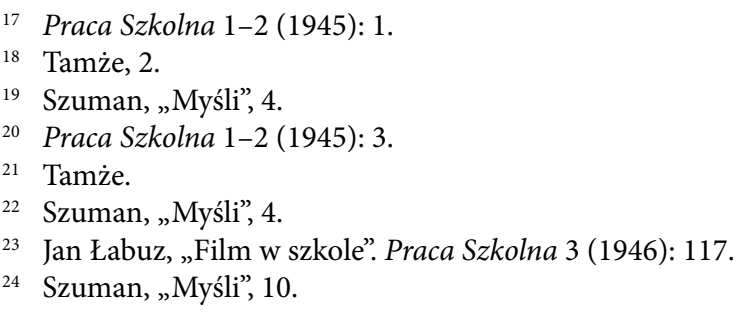


osób dobrze wychowanych może budować oraz pogłębiać swoje człowieczeństwo, dzięki dobrze wykształconej wrażliwości estetycznej. „Nie o znawstwo sztuki chodzi, nie o rozległą, fachową wiedzę w tej dziedzinie, lecz o zdolność dostrzegania i przeżywania prawdziwych wartości estetycznych"25. Autor artykułu nie jest przeciwny „znawstwu”, ale czyniąc tę dystynkcję, pragnie podkreślić główną swoją tezę, że człowiek, u którego zostanie dobrze ukształtowany zmysł estetyczny, „będzie istnienie swoje przeżywał w sposób pełniejszy, głębszy, istotniejszy. Kultura estetyczna, dopełniająca kulturę umysłową i społeczną, tworzy pełnego człowieka”26. Człowiek zaś jej pozbawiony, tj. „człowiek o jednostronnie praktycznym, społecznym, rzeczowym umyśle, jest człowiekiem, który nie zna życia w całej jego pełni i jego głębi” ${ }^{27}$. I jeszcze jedna znacząca uwaga: „Obcujemy z utworami malarstwa i literatury pięknej nie po to, aby uciec od rzeczywistości. Sztuka potęguje naszą wrażliwość na samo życie i uczy nas na nie patrzeć innymi oczyma i świeżym spojrzeniem. Ona właśnie odsłania nam jego urodę"28. Celem kształcenia estetycznej wrażliwości nie był więc eskapizm i szukanie namiastek wobec okaleczonej po wojnie polskiej oraz europejskiej rzeczywistości: „Wychowanie w kulturze artystycznej [...] ma pogłębić kulturę duchową człowieka w odniesieniu do samego realnego życia" ${ }^{29}$. Non scholae sed vitae discimus - ta starożytna zasada była obecna w tworzonych wówczas programach nauczania. Inny autor podkreślał:

W każdym człowieku tkwią wrodzone dyspozycje nie tylko do artystycznego doznawania, lecz i do artystycznej twórczości jako potrzeby życia. [...] Zadaniem szkoły jest kształcenie artystyczne, które należy rozumieć w najszerszym tego słowa znaczeniu jako rozbudzenie i rozwój drzemiących w każdym człowieku dyspozycji i potrzeb do artystycznej twórczości jak i do twórczego doznawania dzieł sztuki. Doprowadzi to w konsekwencji do pogłębienia kultury artystycznej, tzn. do opracowania się własnego, bezpośredniego, aktywnego, wewnętrznego stosunku do dzieł sztuki - do wykształcenia poczucia formy oraz do upowszechnienia i uspołecznienia kultury artystycznej, tj. do zaspokojenia ujawniających się samorzutnie własnych potrzeb artystycznych w sposób rzetelny i właściwy w życiu codziennym każdego człowieka ${ }^{30}$.

W jeszcze innym tekście możemy przeczytać: „Jedną z dróg prowadzących psychikę dziecka do pełnego rozwoju jest kształcenie uczuć estetycznych, pobudzanie twórczości i umożliwianie swobodnego wypowiadania się"31.

\footnotetext{
25 Tamże, 7.

26 Tamże, 6.

27 Tamże.

28 Tamże, 7.

29 Tamże, 8.

30 Edward Kurzyński, „Rysunek w życiu i w szkole”. Praca Szkolna 3 (1947): 43.

31 Małgorzata Baranowska, „Sztuka dziecka”. Praca Szkolna 4 (1947): 40.
} 
W ostatnim dziale „Pracy Szkolnej”, w „Kronice”, odnotowano setną rocznicę wydania Chowanny Bronisława Trentowskiego, podkreślając, że był to "pierwszy polski system pedagogiki filozoficznej”32. Wprawdzie trudno się zgodzić z tym, że „W teorii jego [tj. Trentowskiego] o boskości jaźni tkwi zaczątek przyszłej nauki o osobowości”, ale dyrektywa filozofa, aby równomiernie kształcić „wszystkie władze ciała i duszy”, a więc także rozwijać „uczucie piękności” u dziecka, nie straciła swojej aktualności ${ }^{33}$. W toruńskim „Życiu Szkoły” zastanawiano się "Co deprawuje smak młodzieży?", wskazując konkretne wydawnictwa, zamieszczające "makabryczne [...) historie obrazkowe” i „straszliwie nieortograficzne napisy" ${ }^{34}$. W następnym roku ogłoszono ankietę na temat współczesnych problemów szkolnych. Oto fragment odpowiedzi Kazimierza Sośnickiego: „Czym ma być szkoła $\mathrm{w}$ tym współczesnym przekształcającym się, a więc chwiejnym i niepewnym otoczeniu? Czy ma ona razem $\mathrm{z}$ nim poddać się jego fluktuacji, czy obrać stanowisko jednego ze zwalczających się światopoglądów, czy może odłączając się od ich walki, trzymać się ideału czystej prawdy i niezmiennych ludzkich wartości?” 35 A to wypowiedź Tomasza Szczechury: „Poziom nauczania niewspółmiernie obniżył się w porównaniu ze stanem przedwojennym. [...] Różnica między zaprojektowanym ustrojem szkolnictwa i koncepcjami programowymi a ich realizacją jest tak wielka, że stoimy u progu katastrofy szkolnej: im prędzej to sobie uświadomimy i im prędzej uruchomimy całą skalę środków zaradczych, o tyle zmniejszymi jej skutki”36.

\section{Miejsce nauczania języka polskiego oraz historii w wychowaniu estetycznym}

Pedagogiczne powojenne ideały związane były z programami nauczania i hierarchią ważności poszczególnych przedmiotów. Najważniejszy był język polski. Omawiając wytyczne programowe, przypominano o „kształceniu zmysłu estetycznego i smaku literackiego" ${ }^{37}$, ponieważ: „Nad całym programem języka polskiego widnieje serdeczna troska o język polski, pragnienie, by stał się [...]

32 Ludwik Bandura, „Zapomniana rocznica (w stulecie «Chowanny» Trentowskiego”. Praca Szkolna 3 (1946): 92. Tamże: „[Trentowski] propaguje samorządy uczniowskie daleko przed amerykańskimi twórcami «school-city-system»".

33 Tamże.

34 (sn) Stanisław Nowaczyk, „Na marginesie”. Życie Szkoły 7 (1946): 166-167.

35 Kazimierz Sośnicki, „Najbardzej aktualne i ważne problemy pedagogiczne doby obecnej”. Życie Szkoły 1 (1947): 2.

36 Tamże, 3.

37 Józefa Ziembowa, „Wytyczne nauczania języka polskiego w nowych programach”. Praca Szkolna 1-2 (1945): 16. 
dominantą wśród innych przedmiotów"38. Stawiano smutną diagnozę: „Jaki jest dzisiaj język polski? Okaleczały i ciężki, jak my wszyscy po przebytej wojnie. Wymaga leczenia i pieczołowitej troski” ${ }^{39}$. Autorka artykułu przytacza słowa Lucjana Rydla: „Język to nie tylko środek porozumienia, to wytworzony przez wieki na obraz i podobieństwo charakteru narodowego ukształtowany obraz zewnętrzny najwewnętrzniejszej naszej istoty: żył, rósł i dojrzewał razem z myślą polską, szedł jej drogami, jej cywilizacyjną pracę odzwierciedla w sobie, taki bywał zawsze, jak i myśmy bywali" ${ }^{40}$.

Tuż po zakończeniu działań wojennych, w 1945 roku, wznowiony został ,Język Polski”, „organ Towarzystwa Miłośników Języka Polskiego”, pod redakcją Kazimierza Nitscha. W „Pracy Szkolnej” („Przegląd czasopism”, opracowany przez Tadeusza Kuligowskiego) odnotowano: „Ukazały się trzy numery dwudziestego piątego rocznika "Języka Polskiego», łudząco do przedwojennych podobne" Zawarty $w$ tej informacji przekaz jest wyrazem najwyższego uznania. Jeszcze w 1948 roku możemy w „Pracy Szkolnej” przeczytać: „Być może jednak, iż pewne zjawiska i pozostałości z okresu burzy wojennej i gehenny polskiej z czasu okupacji, smutne przejawy przeobrażenia psychiki młodzieży polskiej w latach zdziczenia, upadku moralności, stępienia wrażliwości etycznej i estetycznej - wzbudziły tęsknotę do ideałów piękna i dobra" ${ }^{32}$. W kontekście wychowania estetycznego ten sam autor proponuje: „Krótki chociażby zarys historii filozofii”, który „zapozna młodzież z najważniejszymi poglądami na istotę piękna"đ3. Warta przemyślenia jest także teza autora głoszącego, że „[...] estetyka społeczeństwa zależy od jego bogact wa" ${ }^{34}$.

$\mathrm{Na}$ drugim miejscu po języku polskim znalazła się historia. „Przedmiot ten bowiem, usunięty zupełnie w czasie okupacji niemieckiej ze szkół polskich, ograniczony był wyłącznie w tym okresie do placówek tajnego nauczania" ${ }^{35}$. Zdawano sobie sprawę, że: „Programy historii zazwyczaj są kompromisem między możliwie pełnym i obiektywnym obrazem przeszłości, a dążeniami aktualnymi twórców programu, ich założeniami politycznymi w najszerszym tego słowa znaczeniu" 46 . Ideałem był jednak „pełny i obiektywny obraz przeszłości”. Historia jawiła się twórcom powojennych programów jako nauka, a nie dowolna „narracja”. Przestrzegano przed niebezpieczeństwem „werbalizmu”: „Werbalizmem w historii nazwiemy [...] używanie słów, których treść nie jest zgodna z ówczesną rzeczy-

\footnotetext{
38 Tamże, 18.

39 Aleksandra Dargielowa, „Język żyje..., tamże, 26.

40 Lucjan Rydel, „Mowa ojczysta”. Poradnik Językowy 6 (1908): 84-86.

41 Tadeusz Kuligowski, Praca Szkolna 1-2 (1945): 36.

42 Michał Dadlez, „Utwór”, 17.

43 Tamże, 18.

44 Tamże, 17.

45 Praca Szkolna 3 (1946): 1.

46 Władysława Martynowiczówna, „Uwagi dotyczące realizacji programu historii”, tamże, 57.
} 
wistością, lub które w ogóle pozbawione są treści”"47. Przeciwieństwem „werbalizmu" miało być także zbliżenie wychowanków szkoły do życia praktycznego. Bliskie to było ideałom „szkoły pracy”, „,szkoły czynu” czy też „szkoły twórczej”. Przy tej okazji odwoływano się do polskich tradycji. Z innego artykułu dowiadujemy się, że historia ma kształtować osobowość ucznia, „budząc w nim przywiązanie do Ojczyzny, poczucie odpowiedzialności za jej losy i humanitarną postawę wobec innych narodów"48.

Pod wpływem potężnych efektów propagandowych przedwojennej propagandy niemieckiej, opartej na pseudonauce, deprecjonującej wszystko, co słowiańskie, na rzecz pierwiastków germańskich, dostrzegano w powojennej Polsce wagę nauczania prehistorii: „Prehistoria w szkole to nie tylko jeszcze jeden przedmiot w programie, ale to ważny czynnik wychowawczy naszego społeczeństwa, dotąd nie doceniany i zapoznany. [...] Brak tego czynnika w wychowaniu młodych pokoleń stanowi lukę, [...] naprawdę niebezpieczną nawet ze względu na politykę prehistoryczną, prowadzoną w szkołach niemieckich”"49, ponieważ: „Przewodnią ideą «nauki» niemieckiej było wykazanie wartości kultury niemieckiej kosztem Słowian”50. Propagowaniu wiedzy na temat Słowiańszczyzny służył „Biuletyn Słowiański”, związany z Ministerstwem Informacji i Propagandy.

\section{Wychowanie estetyczne a demokratyzacja życia społecznego}

Jednym z najważniejszych ideałów w powojennej polskiej pedagogice była demokratyzacja życia społecznego. „Źródłem i natchnieniem jej pracy pedagogicznej zawsze były najpiękniejsze ideały demokracji: wolność, równość, sprawiedliwość społeczna, braterstwo" ${ }^{21}$ - napisano w artykule poświęconym jubileuszowi pracy pedagogicznej Heleny Radlińskiej. Jednym z przejawów demokratyzacji miał być ruch spółdzielczy. Pisząc o spółdzielczości, odwoływano się do Towarzystwa Kooperatystów, które powstało w 1906 roku z inicjatywy Edwarda Abramowskiego. „Pokolenia wychowane w spółdzielczości, przeniknięte ideą spółnego dobra, przyjaźni i samodzielności - jest to ta nowa, oczekiwana, zapowiadana w proroctwach i pieśniach, demokratyczna, niezniszczalna Polska; naród silny, możny, samodzielny, nie uznający przywilejów klasowych ani prawa opartego

47 Stanisław Nowaczyk, „Werbalizn w nauczaniu historii”. Praca Szkolna 4 (1946): 114.

48 Franciszek Zawadzki, „O niektórych aspektach nauczania historii w szkole powszechnej słów kilka”. Praca Szkolna 3 (1946): 53-54.

49 Wanda Sarnowska, „Społeczne znaczenie prehistorii jako przedmiotu nauczania”. Praca Szkolna 9-10 (1947): 381.

50 Tamże.

51 „Helena Radlińska”. Praca Szkolna 9-10 (1947): 370. 
na krzywdzie"52. Tak rzecz ujmował E. Abramowski przed I wojną światową. Po II wojnie, w duchu powojennego profetyzmu, wtórował mu Romuald Mielczarski: „Wychowamy nowy typ człowieka, prawdziwego Europejczyka, kochającego twórczość, wiedzę i wspólne dobro, dalekiego od fanatyzmu, tolerancyjnego dla przekonań cudzych, bo szanującego własne, wrażliwego na hasła wolności, równości i braterstwa" ${ }^{33}$. Spółdzielczość rozumiano jako zaplanowane wspólnie, w sposób nieprzymuszony przez żadne odgórne czynniki i dobrze uprzednio przemyślane działanie na rzecz wspólnego dobra. „Spółdzielczość jest ucieleśnieniem demokracji gospodarczej w życiu społecznym, czyli mówiąc innymi słowy realizacją wolności” - pisał Stanisław Thugutt ${ }^{54}$.

Znaczącą ideą, wymuszoną przez wojnę, było samokształcenie. Chodziło o nadrabianie zaległości, o przyśpieszoną naukę w obszarach wyjątkowo zaniedbanych i wreszcie o podnoszenie kwalifikacji. Można tu odnaleźć inspiracje dla współczesnej zasady permanentnego uczenia się i ciągłego rozwijania swoich kwalifikacji.

W artykule pt. Czy kres pedagogiki personalistycznej? L. Bandura harmonijny rozwój osobowości wiąże z personalizmem. Kończy swój artykuł następująco: „Nie sądzę, by ten ideał się przeżył. Właśnie w ustroju demokratycznym, w którym chodzi o wprowadzenie najszerszych mas w świat wartości, ideał kształtowania osobowości winien znaleźć najpełniejsze zrozumienie" ${ }^{55}$.

Tuż po wojnie zaczął wychodzić miesięcznik pedagogiczny o tytule „Demokracja i Wychowanie", wydawnictwo Instytutu Pedagogicznego w Katowicach, którego programem miało być „służenie demokratycznej Polsce i demokratycznej idei w wychowaniu" ${ }^{56}$. Krytyczna ocena zawartości czasopisma, która ukazała się w „Pracy Szkolnej”, bynajmniej nie oznaczała negatywnego ustosunkowania się do ideałów demokracji: „Niezmiernie ubogi zeszyt pierwszy zdaje się zrywać z dobrą tradycją przedwojennej «Chowanny», budząc w czytelniku uczucie zrozumiałego żalu. Niepotrzebne zgoła są, naszym zdaniem, te ambicje nowatorskie, usiłujące działać na czytelnika blaskiem aktualnych tytułów, modnych wyrazów i pretensjonalnością tematów” ${ }^{57}$. W pierwszym numerze „Demokracji i Wychowania" pisano o reformie studiów na wydziale filozoficznym, sugerując ich upraktycznienie i przystosowanie do zadań szkoły. „Upraktycznienie” staje się czytelne, jeśli oznacza przewagę filozofii praktycznej w programie, natomiast jej „przystosowanie do zadań szkoły” może także oznaczać nasycenie programu filozofii uproszczonymi rozwiązaniami ideologicznymi.

\footnotetext{
52 Praca Szkolna 1-2 (1946): 5.

53 Tamże, 39.

4 Tamże, 49

55 Ludwik Bandura, „Czy kres pedagogiki personalistycznej?”. Życie Szkoły 1 (1946): 270.

56 Wacław Wojtyński, „Przegląd czasopism”. Praca Szkolna 1-2 (1945): 41.

57 Tamże.
} 


\section{Wychowanie estetyczne w klimacie stopniowej ideologizacji życia szkolnego}

Rozbudzanie wrażliwości estetycznej nie zawsze miało miejsce w kontekście ideału rozwoju pełnej osobowości młodego człowieka. Wraz z ideologizacją nauczania, podporządkowanego coraz bardziej bieżącej polityce, na początku niekiedy zupełnie jawnie podkreślano możliwości wykorzystania tego, co piękne, w celach ideologiczno-politycznych. Z końcem 1947 roku w „Pracy Szkolnej” pojawił się szczególny tekst, którego autorka pisze następująco:

Nauczyciel języka rosyjskiego, gdy wchodzi po raz pierwszy do klasy, nie spotyka się z przychylnym nastawieniem młodzieży do tego języka. Młodzież przychodzi do szkoły uprzedzona do Związku Radzieckiego. Nie ma ona zaufania do tego, co nauczyciel o tym kraju opowiada, myśli, że to celowa propaganda. Uprzedzenie to ma charakter wybitnie uczuciowy. [...] jedynym właściwym środkiem do przebicia tej ściany niechęci jest działanie na uczucia młodzieży, poruszenie tych uczuć, pozyskanie ich ${ }^{58}$.

Autorka artykułu proponuje w tym celu uczenie na lekcjach rosyjskiego radzieckich piosenek, które często mają bardzo piękne, porywające melodie: „Niepostrzeżenie dla młodzieży samej porywa ją nie tylko forma (melodia), lecz i treść piosenki” ${ }^{9}$. Ta sama autorka już w następnym numerze „Pracy Szkolnej” (styczeń 1948 roku) pisze o ideale wychowawczym w Związku Radzieckim. Jest nim „człowiek wszechstronnie wykształcony”, opisany przez „teoretyków komunizmu”, Marksa i Engelsa. Jest to ideał wychowawczy „przyszłego społeczeństwa komunistycznego". Obejmuje on pięć działów: wychowanie rozumowe, politechniczne, moralne, fizyczne i - na piątym miejscu - estetyczne ${ }^{60}$. Wartościowe oraz obojętne ideologicznie ustalenia pedagogiczne pod wpływem polityki zaczęto przypisywać coraz częściej kilku wybranym „teoretykom komunizmu”. W ten sposób przyznawano im monopol na wszelką wiedzę, ograniczoną filozoficznie zasadami „materializmu dialektycznego" oraz „materializmu historycznego”. Oba „materializmy” przedstawiano przy tym jako „naukowe” oraz „jedynie słuszne”. To przez te prądy i tendencje, coraz bardziej odczuwalne w prasie pedagogicznej drugiej połowy lat czterdziestych, milkną na jej łamach dyskusje, kontrowersje, a także punkty sporne. Język ubożeje i staje się charakterystyczną „nowomową”, w której zanika wszelki przedmiotowy sens ${ }^{61}$.

58 Ida Altszuler, „Rola piosenki na lekcjach języka rosyjskiego”. Praca Szkolna 4 (1947): 51.

59 Tamże, 52.

60 Ida Altszuler, „Ideał wychowawczy w Związku Radzieckim”. Praca Szkolna 5 (1948): 25-31.

61 Por. „Zadania szkoły w roku szkolnym 1949/50”. Praca Szkolna 1 (1949): 1: „dalsze pogłębianie i nasilenie pracy ideologicznej i wychowawczej szkoly”, „Zwiększenie wydajności pracy dydaktycznej i wychowawczej szkół wszystkich typów i stopni”. 
Podejście do filozofii staje się entuzjastyczne o tyle, o ile dotyczy ona ideologicznej podbudowy polityki ówczesnych władz, sprzężonej coraz ściślejszym węzłem z polityką radziecką. Jeszcze w 1946 roku na wiosnę w „Życiu Szkoły” opublikowano niewielki objętościowo artykuł pt. Znaczenie filozofii dla nauczyciela $^{62}$. Autor przypomina w nim podstawowe wiadomości na temat tego, czym jest filozofia, ugruntowane wielowiekową tradycją, podkreślając, że: „[...] nauczyciel powinien znać choć w głównych zarysach i filozofię" ${ }^{63}$. A oto uzasadnienie: „Metafizyka [...] jest dyscypliną wartościową dlatego, że analizuje krytycznie różne możliwe poglądy na świat. Przy tej analizie korzysta metafizyka z wyników badań poszczególnych nauk w celu syntetycznego ich ujęcia dla ogólnego poglądu na całą rzeczywistość" ${ }^{64}$. Inne działy filozofii także spotykają się z przychylną oceną autora tekstu, w kontekście pracy nauczycielskiej: „Teoria poznania, estetyka, historia filozofii również oddają wielkie usługi znającemu je nauczycielowi: pierwsza dyscyplina, rozwijając krytycyzm poznawczy i zrozumienie możliwości naszej wiedzy - druga, kształcąc uczucia estetyczne, - historia filozofii, dając obraz rozwoju myśli ludzkiej w dziedzinie najogólniejszych i najżywotniejszych zagadnien'" ${ }^{65}$. Za to w tekście zatytułowanym Ogólna charakterystyka nauk pedagogicznych i płynące stąd konsekwencje i wskazania, autorstwa Antoniego B. Dobrowolskiego zamieszczonym w nr 1-2 „Nowej Szkoły”, możemy spotkać się z podejściem zdecydowanie negatywnym do filozofii. Ma ona bowiem stanowić, zdaniem autora artykułu, poważną przeszkodę w tym, aby pedagogikę uczynić prawdziwie naukową dyscypliną ${ }^{66}$. O „Nowej Szkole” informowano w „Pracy Szkolnej”, w dziale „Przegląd czasopism”, że jest „bezsprzecznie dokumentem zupełnie nowego spojrzenia na rzeczywistość" ${ }^{67}$. To ostatnie określenie korespondowało wyraźnie z treściami, jakie zawierało w sobie stwierdzenie: „nowa polska rzeczywistość".

Polska pedagogiczna prasa powojenna dostarczała także informacji o wydawnictwach zagranicznych, przez co rozumiano zarówno najbliższych sąsiadów, jak i Zachód Europy. W „Życiu Szkoły”, w dziale „Przegląd wydawnictw zagranicznych", możemy przeczytać:

Wojna ostatnia była gwałtownym wstrząsem dla ludzkości, toteż podobnie jak u nas, również na Zachodzie zastanawiano się nad zadaniami wychowawczymi na najbliższe

62 Franciszek Idan, „Znaczenie filozofii dla nauczycieli”. Życie Szkoły 3-4 (1946): 43-45. Artykuł uzupełniony został listą lektur, które mogą uzupełnić filozoficzne wykształcenie nauczyciela. Posród nazwisk autorów znajdujemy Kazimierza Ajdukiewicza, Tadeusza Czeżowskiego, Tadeusza Kotarbińskiego i Władysława Tatarkiewicza.

63 Tamże, 43.

64 Tamże, 44.

65 Tamże, 45.

66 „Rozmowa z Czytelnikami”. Życie Szkoty 3-4 (1946): 82.

${ }^{67}$ Praca Szkolna 1-2 (1945): 40. Nowa Szkoła - miesięcznik, organ Ministerstwa Oświaty, Warszawa - Łódź; 1-2 (1945). 
lata. Dyrektor gimnazjum w Lozannie, Louis Meylan, ogłosił dwie ciekawe prace, w których rozwija tezę, że należy w wychowanku „rozwinąć wszystkie siły, które tworzą człowieka”. Wychowanie winno być harmonijne, wartości winno szukać nie tylko $\mathrm{w}$ wiedzy, ale i w sztuce. Ideał ten powinien objąć wszystkie klasy społeczne. Wartości tych należy szukać nie tyle w przeszłości, co w przyszłości - należy sobie zdać sprawę, ku czemu ludzkość dąży (Les humanités et la personne, 1939). Nauczyciel realizujący ten ideał powinien być $\mathrm{z}$ usposobienia poetą, bo poezja posiada siły twórcze zdolne do przetworzenia dziecka. Literatura i sztuka przyczynią się do zharmonizowania czlowieka (L'élément poétique dans l'éducation, Zurych 1939). Podobne myśli znajdujemy w książce Rosselo Allons nous vers une Ecole d1 action, de raison ou de passion? (Genewa 1944), której autor twierdzi, że szkoła winna doprowadzić do harmonijnej syntezy czynu, rozumowania i uczucia ${ }^{68}$.

Rozwój estetyczny miał wspomagać wspieranie moralne ucznia, ponieważ u młodzieży powojennej obserwowano „osłabienie woli i wiary w życie”. Remedium na te bolączki było kształtowanie osobowości oraz charakteru młodego człowieka $^{69}$. Bardzo ważna wydaje się następująca konstatacja: „Jak widzimy z powyższego pobieżnego przeglądu, pedagogika Zachodu zwrócona jest ku człowiekowi i silne są w niej tendencje neohumanistyczne. Ten sam kierunek zaznaczył się u nas w Polsce na dwóch zjazdach pedagogicznych w Łodzi. Mimo odcięcia nas od myśli obcej zauważyć się daje pewna równoległość myśli"70. Tuż po wojnie neohumanizm oznaczał dbałość o integralne wychowanie człowieka, w którym nie byłaby pominięta ani zaniedbana żadna sfera ludzkiej aktywności. Tak wyrażała się główna idea ówczesnej pedagogiki europejskiej, jaką było likwidowanie strat wojennych w kulturze i, co za tym idzie, powojenna odbudowa życia. Pedagogika polska twórczo współtworzyła ten nurt.

\section{Podsumowanie}

Przedwojenne oraz powojenne ideały pedagogik - w omawianym tutaj okresie dotyczyły zdobywania wiedzy, wychowania obywatelskiego oraz uwrażliwienia młodego człowieka na głęboki sens oraz piękno ludzkiego życia, poprzez wyrabianie w nim wrażliwości estetycznej. Wszystkie one opierają się na opracowanej jeszcze w średniowieczu nauce o trancendentaliach, której korzenie tkwią w starożytnej greckiej paidei: prawdzie, jako ideale związanym ze zdobywaniem wiedzy, dobru jako celu i zarazem zasadzie, regulującej relacje społeczne,

68 Życie Szkoły 3-4 (1946): 77. Nie brakło także informacji o pedagogice opartej na filozofii spirytualistycznej: „Znany i u nas pedagog Adolf Ferriéére w książce «Liberation de l’homme» (Genewa 1942) wyraża swoją filozofię spirytualistyczną i twierdzi, że wychowawca powinien dziecku pomóc wznieść się do Boga" - tamże.

69 Tamże, 77.

70 Tamże, 78. 
ze szczególnym podkreśleniem dbałości o dobro wspólne oraz pięknu, jako istotnej cesze prawdziwie ludzkiego życia. „Wychowanie estetyczne może śmiało wyjść $\mathrm{z}$ założenia, że w naturze ludzkiej od urodzenia drzemią potrzeby estetyczne, które się z wiekiem budzą i rozwijają"71. Dlatego też „[... [ w obcowaniu z utworami prawdziwej i wartościowej sztuki zdobywamy nowy, estetyczny smak rzeczywistości, który pozwala nam zwrócić się do rzeczywistości realnej ze spojrzeniem artystycznie wnikliwym, rozumiejącym samą urodę i samą, przenikającą nas, głębię rzeczywistości”72. Owa głębia odsłania istotne piękno rzeczywistości, poznanie jej pozwala więc także tą rzeczywistością się zachwycić. „Kultura duchowa jest nie tylko kulturą umysłu i wiedzy, ale jest kulturą przeżyć" ${ }^{\prime 3}$. Najważniejsze staje się "przyswajanie sobie” utworów estetycznych, „fakt kształtowania osobowości przez ten pokarm, fakt wzbogacania, rozbudowy i pogłębiania osobowości [...]"74. Bez wątpienia w kontaktach ze sztuką oraz w ogóle - z pięknem - chodzi więc o jakość człowieczeństwa, renesansowej humanitas.

Jeszcze w roku 1947, na początku kolejnego numeru „Pracy Szkolnej” jego redaktorka zwracała uwagę na to, że „optimum wytwarzania dóbr”, a nie ich spożycie, jest właściwym źródłem „pełnego rozwoju człowieka: jego uczuć moralnych i estetycznych, składających się na radość życia"75. Już wtedy dostrzegano niebezpieczeństwa związane z mechanizacją wytwórstwa oraz produkcji tego wszystkiego, co otacza bezpośrednio człowieka, tworząc najbliższy mu świat ${ }^{76}$. „Prawdziwa kultura artystyczna wyrabia smak estetyczny" ${ }^{77}$, pisał Szuman, a „Wyrobiony smak estetyczny szereguje łatwo utwory, z którymi się styka, na dzieła sztuki prawdziwej i wytwory pseudo-sztuki"78. Mamy więc tutaj do czynienia ze spiralą rozwojową, przy czym u początków rozwoju smaku estetycznego u dziecka ważny jest wybór tego, z czym się ono styka, po to, aby dzięki ukształtowanemu prawidłowo zmysłowi piękna człowiek dojrzały, „pełny”, mógł już samodzielnie dokonywać pod tym względem prawidłowych wyborów.

Jak bardzo one okazały się ważne, możemy pojąć, wczytując się na nowo w sensy wiersza Zbigniewa Herberta pt, Potęga smaku. Przypomnijmy więc początek: „To wcale nie wymagało wielkiego charakteru / nasza odmowa niezgoda i upór / mieliśmy odrobinę koniecznej odwagi / lecz w gruncie rzeczy była to sprawa smaku / Tak smaku / w którym są włókna duszy i chrząstki sumienia"

71 Szuman, „Myśli”, 11.

72 Tamże, 7.

73 Tamże, 6.

74 Tamże, 77.

75 Władysława Hoszowska, „Wychowawcze znaczenie pracy ręcznej w dzisiejszej szkole ogólnokształcącej”. Praca Szkolna 1 (1947): 4.

76 Tamże: „[...] budzi się [...] tęsknota do dzieła rąk kształtowanego od początku do końca przez to samo poczucie piękna i harmonii. W świetle tego przejawu np. warszawski szewc - artysta, niezrównany w swoim rzemiośle, nie jest przeżytkiem, tylko człowiekiem przyszłości”.

77 Szuman, „Myśli”. Praca Szkolna 3 (1946): 77.

78 Tamże. 
i wciąż nazbyt lekko, jak się wydaje, odczytywaną sentencję: „Tak więc estetyka może być pomocna w życiu / nie należy zaniedbywać nauki o pięknie”.

Streszczenie: Artykuł analizuje wybrane wątki z polskich czasopism, wydawanych po zakończeniu wojny, w bardzo trudnych warunkach. Podstawę analiz stanowią teksty zamieszczone w „Pracy Szkolnej”, w „Życiu Szkoły” oraz innych periodykach z tego okresu. Treści, dotyczące ideałów wychowawczych, nawiązywały do projektów przedwojennych. Były one oparte na wyrazistej aksjologii oraz filozofii człowieka i znajdowały wyraz w konkretnych propozycjach programowych. Wychowanie dotyczyć miało przede wszystkim „likwidacji skutków wojny". Pod wpływem tendencji politycznych, które współtworzyły ówczesną "nową polską rzeczywistość”, zmieniał się język tych artykułów. Socjalistyczna ideologia i towarzysząca jej nowomowa stopniowo wypierały wszelkie ślady dyskusji nad wartościami $\mathrm{w}$ pedagogice.

Słowa kluczowe: przełom historyczny, cezura wojny, niezmieniony ideał, nowa agresywna ideologia

\section{Bibliografia}

Abramowiczówna, Zofia, red. Słownik grecko-polski, Warszawa: Państwowe Wydawnictwo Naukowe, t. II, 1960; t. III, 1962; t. IV, 1965.

Altszuler, Ida. „Rola piosenki na lekcjach języka rosyjskiego”. Praca Szkolna 4 (1947): 51-53.

Altszuler, Ida. „Ideał wychowawczy w Związku Radzieckim”. Praca Szkolna 5 (1948): 25-31.

Bandura, Ludwik. „O wznowienie wydawnictw pedagogicznych”. Praca Szkolna 4 (1946): 131-133.

Bandura, Ludwik. „Czy kres pedagogiki personalistycznej?”. Życie Szkoły 11 (1946): 267-270.

Baranowska, Małgorzata. „Sztuka dziecka”. Praca Szkolna (1947): 40-43.

Czarnowski, Kazimierz. „Głos w dyskusji”. Praca Szkolna 4 (1946): 126-129.

Dadlez, Michał. „Utwór literacki jako czynnik wychowania estetycznego”. Praca Szkolna. 8 (1948): $17-22$.

Dargielowa, Aleksandra. „Język żyje...”. Praca Szkolna 1-2 (1945): 24-27.

Hoszowska, Władysława. „Szkoła polska a ruch spółdzielczy”. Praca Szkolna 1-2 (1946): 7-18.

Hoszowska, Władysława. „Wychowawcze znaczenie pracy ręcznej w dzisiejszej szkole ogólnokształcącej”. Praca Szkolna 1 (1947): 1-8.

Kostkiewicz, Janina. Kierunki i koncepcje pedagogiki katolickiej w Polsce 1918-1939. Kraków: Oficyna Wydawnicza „Impuls”, 2013.

Kostkiewicz, Janina. „Wprowadzenie. Zarys pedagogiki ogólnej Andrzeja Niesiołowskiego - o koncepcji i jej rękopisie powstałym w niemieckich oflagach”, 13-67. W: Andrzej Niesiołowski, Zarys pedagogiki ogólnej. Rękopisy z oflagu, odczytanie i oprac. Janina Kostkiewicz. Kraków: Wydawnictwo Uniwersytetu Jagiellońskiego, 2017.

Kuligowski, Tadeusz. „Przegląd czasopism”. Praca Szkolna 1-2 (1945): 36-40.

Kurzyński, Edward. „Rysunek w życiu i w szkole”. Praca Szkolna 3 (1947): 39-44.

Łabuz, Jan. „Film w szkole”. Praca Szkolna 3 (1946): 97-144.

Martynowiczówna, Władysława. „Uwagi dotyczące realizacji programu historii”. Praca Szkolna 3 (1946): 56-63. 
Miężyński, Kazimierz. „Rola pomocy naukowych na lekcjach języka polskiego w Polsce dzisiejszej”. Praca Szkolna 5-6 (1947): 221-224.

Mochnacki, Maurycy. „Myśli o literaturze polskiej”, 102-146. W: Rozprawy literackie, Wrocław 2004.

Nowaczyk, Stanisław. „Werbalizn w nauczaniu historii”. Praca Szkolna 4 (1946): 114-117.

Radlińska, Helena. „Szkoła w walce z ujemnymi skutkami wojny w dziedzinie moralności (dokończenie)". Praca Szkolna 9-10 (1947): 370-375.

Sarnowska, Wanda. „Społeczne znaczenie prehistorii jako przedmiotu nauczania”. Praca Szkolna 3 (1946): Praca Szkolna 9-10 (1947): 381-386.

Sośnicki, Kazimierz. „Najbardzej aktualne i ważne problemy pedagogiczne doby obecnej”. Życie Szkoły 1 (1947): 1-3.

Szuman, Stefan. „Myśli o kształtowaniu kultury estetycznej - wychowawców i wychowanków nowej szkoły polskiej”. Praca Szkolna 1-2 (1945): 4-12. Dokończenie 3 (1946): 75-79.

Tatarkiewicz, Władysław. Historia estetyki, t. I, Estetyka starożytna. Wrocław - Warszawa - Kraków: Zakład Narodowy im. Ossolińskich - Wydawnictwo, 1962.

Wojtyński, Wacław. „Ćwiczenia słownikowe w nowym programie szkoły powszechnej”. Praca Szkolna 1-2 (1945): 31-35.

Zawadzki, Franciszek. „O niektórych aspektach nauczania historii w szkole powszechnej - słów kilka”. Praca Szkolna 3 (1946): 53-56.

Ziembowa, Józefa. „Wytyczne nauczania języka polskiego w nowych programach”. Praca Szkolna 1-2 (1945): 12-18. 